\title{
NA OBRANU VÁGNOSTI
}

ANDREJ DÉMUTH, Univerzita Komenského v Bratislave, Právnická fakulta, Bratislava, SR MAREK ŠTEVČEK, Univerzita Komenského v Bratislave, Právnická fakulta, Bratislava, SR

DÉMUTH, A., ŠTEVČEK, M.: Defending Vagueness

FILOZOFIA, 76, 2021, No 4, pp. 237 - 251

Philosophers often consider vagueness (a linguistic expressions admits of unclear or borderline cases of application) to be an undesirable phenomenon. The authors of the text reject the existence of ontological vagueness, and, in cooperation with T. Williamson, they find the roots of vagueness in insufficient understanding. Apart from epistemological vagueness, though, they advocate for the existence of semantic vagueness, stemming from the ambiguity and inconsistency of boundaries and ranges of linguistic expressions. While agreeing with the impossibility of complete elimination of semantic vagueness, the authors point to its possible advantage in daily communication and its possible progressiveness in the search for newer, better understanding.

Keywords: Vagueness - Ontological - Epistemicism - Semantic - Contextualism Meaning

\section{Úvod}

Vágnost' patrí medzi závažné problémy filozofického bádania, a tak nečudo, že sa mu venuje nemalá pozornost'. Podstatou problému je, že niektoré javy alebo pojmy nie sú dostatočne určité, respektíve že pojem alebo jazykové vyjadrenie odkazujú na nejaký jav alebo objekt iným ako jasným, konkrétnym a jednoznačným spôsobom. ${ }^{1}$ Klasickým príkladom vágneho odkazovania je pojem „holohlavý“ (ide o jeden z variantov tzv. sorités paradoxov). Je zrejmé, že niektorí l’udia sú holohlaví, a iní zas nie. Problémom nie sú jednoznačné prípady použitia tohto pojmu, ale skôr hranica určujúca významový obsah daného pojmu. Inak povedané: otázne je, kedy pojem možno používat' v zmysle nespornej jazykovej konvencie, a kedy, naopak, už nie. Existuje nejaký určitý počet vlasov, ich hrúbka, hustota či iné vlastnosti, ktoré sú dostatočným a určujúcim kritériom (ne)holohlavosti? Kto a na základe akých kritérií určuje existenciu takejto hranice medzi takzvanými hraničnými prípadmi? Problém vágnosti sa

\footnotetext{
${ }^{1} \mathrm{Na}$ tomto mieste je vhodné hned' v úvode odlíšit' vágnost' (nejasnost') od dvojznačnosti a viacznačnosti, ako aj od všeobecnosti (porov. Sorensen 2018). Podrobnejšiu literatúru k rôznym teóriám a príkladom vágnosti možno nájst' napríklad na stránke Bobzien, S.: Vagueness and Indeterminacy. [online] Dostupné na https://philpapers.org/browse/vagueness-and-indeterminacy/ (Navštívené: 1. 2. 2021).
} 
nevyskytuje iba v bežnej jazykovej konvencii prirodzeného, hovorového jazyka, ale môže spôsobovat' problémy aj v jazyku odbornom. Naším zámerom v tomto príspevku je rozlíšit' sémantický a ontologický aspekt vágnosti a pokúsit' sa obhájit' tézu, že ak sa už vágnosti nedá vyhnút' (čo bude zrejme pravidlo), treba s ňou pracovat' - ba čo viac, $\mathrm{v}$ istých sedimentoch odborného jazyka môže byt' aj progresívnym prvkom.

\section{Epistemicizmus}

V roku 1994 publikoval Timothy Williamson svoju prácu Vagueness (Williamson 1994), v ktorej riešil problém vágnosti postulovaním pozície epistemicizmu. Ide o jedno z možných riešení paradoxov vágnosti jazyka, nie však o riešenie jediné. ${ }^{2}$ Epistemicizmus hlása, že vágnost' jednotlivých pojmov tkvie v nevedomosti - v ,absencii poznania“ -, teda v nedostatku informácií o nejakej skutočnosti, ktorá je predmetom nášho súdenia. Táto nevedomost' môže pochádzat' $\mathrm{z}$ dvoch zdrojov - po prvé z nedostatku relevantného a spol'ahlivého poznania o veciach samých, a to bud' preto, že tieto samy sú „nejasné“, alebo preto, že „nejasné“ je naše poznanie o nich. Je tu však aj iný možný dôvod, ktorý, ako uvádza Zoltán Vecsey, predstavuje vágnost' v podstatne zložitejšom - lingvistickom svetle. „Absencia vedomostí“ znamená niečo silnejšie ako sám nedostatok epistemicky relevantných informácií: v zásade to znamená „nevedomost’ sémantických hraníc neurčitých predikátov“(Vecsey 2012, 179). Je to teda problém hraníc pojmov a nášho myslenia.

V predkladanej štúdii sa pokúsime vysporiadat's oboma problémami (ontologickou vágnost'ou a epistemickou či sémantickou vágnost'ou), ktoré epistemicizmus so sebou prináša.

\section{Problematickost' ontologickej vágnosti}

Problém existencie ontologicky neurčitých objektov má dlhé korene. Môžeme sa s ním stretnút' už $\mathrm{v}$ antickom myslení a vari najznámejším príkladom takéhoto uvažovania je spomínaný paradox hromady (Hyde, Rachman 1997), ale aj paradox zmeny či paradox Tézeovej lode, ktorý tematizuje problém identity v čase. Podstatou tohto problému je presvedčenie, že existujú objekty sveta - vágne objekty -, ktoré nemajú presné hranice (či už v priestorovom alebo v temporálnom ponímaní). Takými môžu byt' napríklad oblaky, hranica hory a podobne., alebo napríklad identita plodu či diet'at'a (koniec obdobia chlapca a začiatok obdobia muža) a mnoho d'alších. Petr Dvořák vo svojej štúdii Je vágnost' sémantický či ontický fenomén? uvádza: „... zdá sa, že všetky objekty makrosveta sú vágne“ $(2019,486)$. Dôvodom pre takýto postoj je skutočnost', že ,príslušnost’ niektorých častíc k stolu alebo k jeho okoliu je neurčitá -

\footnotetext{
${ }^{2} \mathrm{~K}$ d’alším riešeniam zarad’ujeme napríklad rôzne varianty valuacionistických (viac-, super-, sub-), prípadne kontextualistických riešení a pod.
} 
patria častice ešte k stolu (respektíve tvoria jeho povrch), alebo už nie?“ (Dvořák 2019, $485-486)^{3}$ Podobne možno uvažovat' o mnohých iných objektoch, a to i napriek tomu, že tieto sú často tvorené objektmi, ktorých identitu a hranice vnímame vel'mi ostro a jednoznačne. Príkladom takýchto určitých objektov sú podla Dvořáka mikročastice. Odhliadnuc od spornosti toho, či sú objekty mikrosveta naozaj také jasné a jednoznačné ${ }^{4}$ a či skutočne môžeme „vnímat“" identitu povedzme protónu, základnou otázkou Dvořákových skúmaní je, ,či možno hovorit’ o vágnych objektoch, ktoré sú tvorené množstvom presných objektov, napr. agregátov častíc s určitým tvarom na určitom mieste, ktoré sa do značnej miery prekrývajú, ale v niektorých častiach sa líšia“ (Dvořák 2019, 486). Je ich vágnost' neurčitostou poznania (významu), alebo je ich neurčitost' záležitost'ou reality?

Dvořákova štúdia smeruje k sporu s klasickým Evansovým argumentom o nemožnosti reálnej existencie objektov s neurčitou identitou (Evans 1978). Evans vo svojom argumente predpokladá, že neurčité objekty by museli implikovat' o sebe nekoherentné jednoznačné a platné výroky, čo by znamenalo, že niektoré z protirečivých výrokov nie sú platné, respektíve že takéto objekty implikujúce nekoherentnost' nemôžu existovat'. Dvořákov článok sa pokúša preukázat' námietky proti Evansovmu argumentu, respektíve to, že existencia určitých vágnych objektov s neurčitými hranicami je zlučitel'ná s pôvodným Evansovým argumentom, že môžu existovat' ontologicky neurčité objekty. Základným nedostatkom Dvořákovej koncepcie je podla nášho názoru fakt, že pre fenomén neostrosti nie je „neostrost"“ objektov potrebná.

Postoj epistemicizmu, ktorý sa pokúsime tematizovat', je založený na odmietnutí delenia reality na ontologickú a epistemickú. Väčšina zástancov existencie ontologickej neurčitosti verí, že naše poznanie disponuje schopnost'ou zachytit' stav vecí tak, ako sú. Problémom podl'a nich je, že niektoré veci jednoducho sú neurčité samy osebe. Naproti tomu Timothy Williamson vo svojom argumente o vágnosti uvádza, že hromada piesku, ktorá pozostáva z jednotlivých zrniečok, je hromadou vtedy a len vtedy, ak má minimálne istý počet zrniečok. Po odobratí čo i len jedného zrnka piesku prestane spíňat' podmienku byt' hromadou a naopak, po pridaní jedného zrniečka piesku tesne pod takto stanovenou ${ }^{5}$ hranicou sa zasa hromadou stane. Medzi oboma

\footnotetext{
${ }^{3} \mathrm{Na}$ tomto mieste je však potrebné uviest', že pri pojme stôl neidentifikujem častice. Ak sa pozeráme na kúsok hranice stola mikroskopom, tak sme zmenili univerzum úvahy oproti identifikácii makroskopických stolov, a teda aj pojmovú sústavu.

${ }^{4}$ Vnímame mikročastice naozaj ostro a jednoznačne? Okrem skutočnosti, že ich priamo nevidíme a na ich vnímanie potrebujeme prístroje, čast' subelementárnych častíc môže byt' aj významovo nejasná (dosial' neujasnené vlastnosti daných objektov) a niektoré ich aspekty možno vnímat' ostro len vtedy, ak iné budú neurčité - porovnaj Heisenbergov princíp neurčitosti (Heisenberg 1927).

${ }^{5}$ Otáznym tu ostáva, kto a na základe čoho určuje uvedenú hranicu.
} 
stavmi veci neexistuje žiadny d'alší priestor (pol zrniečka, malé zrniečko...) pre neurčité hraničné prípady. Existujú len určité stavy vecí. Veci sú také, aké sú, a neurčitost' nie je záležitost'ou reality (tá je vždy nejaká), ale skôr výlučne záležitost’ou poznania. ${ }^{6}$ Problém tkvie v tom, že vždy nie sme schopní presne určit', aký bude výsledok aplikácie pojmu na daný stav a objekt. Čo je pritom dôležité, neurčitost' podl'a Williamsona nepochádza z neurčitosti pojmu (ten môže byt' precízne zadefinovaný napríklad tak, že hromada bude presne x zrniečok), ale z našej neschopnosti spoznat' a rozhodnút', či daný jav je subsumovatel'ný pod pojem (resp. či bude patrit' do rozsahu pojmu) alebo nie. S prvou čast'ou Williamsonovho epistemického postoja (teda s odmietnutím ontologickej neurčitosti) súhlasíme, s druhou však celkom nie. Nazdávame sa, že popri epistemickej vágnosti existuje aj osobitý typ sémantickej neurčitosti, a teda že neurčitost' môže vyplývat' aj zo samého pojmu, nie len z epistemickej neschopnosti rozhodnút', či je jav pod pojem subsumovatel'ný. Opodstatnenost' takéhoto presvedčenia sa pokúsime preukázat'.

\section{Problém epistemickej neurčitosti ${ }^{7}$}

Podl'a Williamsona neurčitost' vzniká ako nedostatok adekvátneho poznania o veciach. Tento nedostatok, ako sa nazdávame, môže byt' dočasný (zatial' nedisponujeme všetkými relevantnými informáciami, ale pri bližšom skúmaní možno poznatky získat' alebo spresnit') alebo trvalý. Trvalá neprístupnost' informácií môže byt' zapríčinená povahou nášho kognitívneho aparátu (neschopnost'ou získavat' a spracovat' nejaký typ informácií), alebo naopak samotnou neurčitou povahou nejakého objektu, ktorý sa môže vyskytovat' vo viacerých odlišných modalitách. ${ }^{8}$ Práve takýto prípad sa snažia skúmat' zástancovia nemožnosti existencie neurčitých objektov, ktorí - čerpajúc najmä z aristotelovskej logiky - predpokladajú, že existujúca vec musí mat' jednoznačné charakteristiky, a preto nemôže byt' zdrojom platných protirečivých úsudkov. A hoci z dejín vedy poznáme koncepty, ktoré operujú s „,neurčitost'ou“ ako charakteristickým princípom, väčšina $\mathrm{z}$ nich zväčša túto neurčitost’ presunie z roviny reálnej existencie entít do roviny neurčitosti a nejasnosti našej interpretácie javov.

Eliminácia rozštiepenia reality na ontologickú rovinu a epistemickú rovinu nemá len svoje metafyzické opodstatnenie (prečo uvažovat' o veciach aké sú, ak sú nám prístupné len ich javy?), ale prenáša t’ažisko problému najmä do epistemologickej roviny.

${ }^{6}$ „Zdrojom akejkol’vek nejasnosti je náš spôsob konceptualizácie stavu vecí, nie samotný stav veci““ (Williamson 2003, 709).

${ }^{7}$ Pre úplnost' uvádzame, že vágnost' je len jedným druhom neurčitosti, teda neurčitost' je rozsahovo širši pojem ako vágnost'.

${ }^{8}$ Túto možnost' sme už vyššie odmietli. 
Jedným z vážnych dôvodov, pre ktorý nevieme určit či daný jav patrí alebo nepatrí pod zvolené kritérium (napr. hromady piesku alebo plešatosti), je problém zaujat' primeranú a celostnú perspektívu. Dvom konkurenčným pohl'adom (analytickým „zdola“ a holistickým „zhora“) zodpovedajú dve odlišné konceptuálne sústavy. Antinómia „hromady“ tak vzniká preto, lebo preskakujeme medzi dvoma konceptuálnymi sústavami nekontrolovane. Pre posúdenie počtu zrniečok piesku v hromade musíme zaostrit' svoju pozornost' na vel'mi malú mierku, ktorá nám umožňuje diskriminovat' všetky podstatné detaily. Stáva sa však, že jednoducho nedisponujeme takou dobrou rozlišovacou schopnost'ou, aby sme vedeli jasne rozlíšit' všetky podstatné detaily, alebo že takéto postihovanie je technologicky či energeticky, ale aj časovo náročné. $\mathrm{Na}$ druhej strane, keby sme aj zrátali presný počet vlasov na hlave človeka alebo presný počet zrniečok $\mathrm{v}$ hromade piesku, $\mathrm{z}$ tejto detailnej perspektívy nemusíme ešte vediet' celkom zmysluplne zaujat' postoj, či ide naozaj o holohlavého človeka alebo o hromadu piesku, ked’že na to potrebujeme zaujat' širšie stanovisko a celostnejšiu perspektívu (musíme vidiet' nielen počet vlasov, ale aj ich hrúbku, dížku, vzhl'ad..., ale aj celok, teda to, že ide o hlavu, hromadu a pod...). Vždy však nemožno zaujímat' postoje, ktoré nám epistemicky umožnia rozlišovat' všetky podstatné elementy daného javu a zároveň aj ich celostnú štruktúru. Inými slovami, vel'mi často nie sme schopní kontrolovat' zmenu konceptuálnych sústav počas prehovoru.

Z kantovských a postkantovských epistemologických úvah vieme, že predmet nášho skúmania je vždy do istej miery naším konštruktom. ${ }^{9}$ A to v tom zmysle, že okrem zmyslových dát či iných „substrátov“ skúsenosti, ktoré sú vždy konštituované štruktúrou daného senzorického či kognitívneho aparátu, neexistuje „čistý“ prístup $\mathrm{k}$ týmto dátam. To, s čím sa stretávame, je vždy kontaminované naším predporozumením a explanačným pozadím, z ktorého vychádzame. Týka sa to ako objektov prírodovedného poznania (mikročastice ako ich reprezentácie sú modelmi a sú opisované hypotézami, ktoré sú zakorenenými v celej sieti hypotéz o svete - Quine, Duhem, Kuhn... $)^{10}$, tak aj objektov spoločenského a humanitného poznania. Práve pri nich sa najvýraznejšie ukazuje, že to, čo vnímame ako „ten istý“ jav (napríklad isté konanie), máva svoj význam hlboko zakorenený v interpretáciách a presvedčeniach pozorovatel’a, a tie sa neraz od subjektu $\mathrm{k}$ subjektu značne odlišujú. Možno to vidiet’ na príkladoch odlišností interpretácií „tých istých javov“ nezúčastneného a zúčastneného pozorovatel’a. Kým jeden pri interpretácii neraz vychádza najmä z dôsledkov, druhý sa zameriava

\footnotetext{
9 Je pritom zaujímavé, že pôvodné vymedzenie epistemicizmu Timothyho Williamsona bolo na základe jeho epistemického realizmu, a teda presvedčenia, že svet spoznávame viac-menej taký, aký je, ale naša diskriminácia sveta nemusí byt’ dostatočne jasná a jeho konceptualizácia dostatočne jemná. ${ }^{10}$ To samozrejme neznamená, že mikročastice majú „dve“ zložky - ontologicky nezávislú a konceptuálnu. Quine ako nominalista by zrejme takúto hybridnú teóriu neprijal.
} 
na možné intencie a východiská. A tie samy osebe často vôbec nemusia byt' jednoznačné. A to ani v prípade pozorovatel'a, ktorý bol zároveň aktérom posudzovaného konania. I uňho môžu byt' skutočné príčiny, presnejšie motívy jeho konania celkom neurčité, a to nielen preto, že mnohé z nich nemusí poznat' (nemusí si ich byt' vedomý, napríklad ak koná reflexívne či impulzívne), ale aj preto, že sa môžu skladat' z množstva rôznych a často navzájom nevyjasnených a poprepletaných motívov.

\section{Princípy sémantickej neurčitosti}

Riešením otázky vágnosti preto nie je skúmanie možnej neurčitosti vo svete, ale skôr skúmanie hraníc aplikovatel’nosti jednotlivých významov jazykových výrazov. Viacero filozofov sa nazdávalo, že vágnost' možno z jazyka odstránit' prostredníctvom spresňovania nášho vyjadrovania. S tým sú však späté hned' dva problémy. Tým prvým je problém ekonomickej i sémantickej náročnosti presného a jednoznačného vyjadrovania. Ako vyplýva zo štúdií F. Gahéra, M. Števčeka a M. Braxatorisa (2019), ale aj F. Gahéra, M. Mrvu, M. Števčeka a M. Turčana (2020) „,požiadavka presnosti, jednoznačnosti, je akoby v nepriamom pomere k požiadavke stručnosti: čím je text presnejší, jednoznačnejší, tým je rozsiahlejšsi' (Gahér et al. 2020, 310). V prípade mnohých, najmä informatívnych textov, ktoré majú poskytovat' návody či pokyny aplikovatel'né v rozličných situáciách, sa tak stáva, že intencia autora musí byt' vyjadrovaná vel'kým počtom spresňujúcich pojmov a termínov, čo neraz vedie $\mathrm{k}$ značnej obsiahlosti textu, jeho neprehl'adnosti a náročnosti, a to aj napriek často používaným metódam zhutňovania textu. Vo filozofickej logike preto pre odstránenie akceptácie problémov neurčitosti neraz siahame po „neštandardných“ logických nástrojoch, ako sú používanie viachodnotovej logiky (napr. aj fuzzy logiky), prostriedkov supervaluacionizmu, alebo naopak subvaluacionizmu a podobne. ${ }^{11}$ Inými slovami: ak chceme zaručit' čo najvyšší stupeň jednoznačnosti a presnosti našich vyjadrení, často musíme zavádzat' spresňujúce termíny a prostriedky až do takej úrovne, aby čo najväčšmi zamedzili nebezpečenstvu nejednoznačnosti a neurčitosti používaných pojmov. A to výpoved' zneprehladňuje. Gahérom spomínaná nepriama úmera medzi presnost'ou a strohost'ou vyjadrenia (príliš zjednodušený či nadmieru koncízny text môže byt' významovo nejednoznačný či nezrozumitel'ný, čo v aplikačnej praxi môže viest' $\mathrm{k}$ chaosu a zmätkom) či Holländerov paradox právneho jazyka (Holländer 1995) tak pripomínajú sémantickú verziu Heisenbergovho princípu neurčitosti. Bud' je text celkom presný, ale potom môže byt' pre svoju detailnost' t'ažko zrozumitel'ný, alebo je zrozumitel'ný, ale

\footnotetext{
${ }^{11}$ Bližšie pozri napr. Peregrin (2004, 57 a nasl.).
} 
potom nemusí byt' dostatočne presný. ${ }^{12}$ Použime na pomenovanie tohto javu, typického pre normatívne texty či jazykové výrazy typu „,̌o má byt‘“, výraz Gahér-Holländerov paradox normatívnych viet.

Analógia s Heisenbergovým princípom neurčitosti nie je celkom náhodná (hoci v zmysle predchádzajúcej vety vd'aka svojej nepresnosti môže byt' zrozumitel'ná). Heisenberg totiž objavil nielen to, že nie je možné súčasne vyjadrit' vel'kost' dvoch konjugovaných veličín, ale aj to, že presnost' vyjadrenia každej z nich osobitne má svoje limity. To znamená, že určit' napríklad polohu alebo hybnost' nejakej častice nemožno s absolútnou presnost'ou. ${ }^{13}$ Podobne aj zástancovia čo najväčšej presnosti a určitosti sémantických jednotiek zistili, že pojmy sa môžeme pokúšat' spresňovat' ako len chceme, ale ich dokonalú určitost' a presnost' celkom nedosiahneme. Aj určitost' a presnost' má svoje limity. V niektorých prípadoch, akým je napríklad normatívny jazyk právnych predpisov, má byt' ambíciou normotvorcu o túto limitu sa usilovat', aj ked' ju úplne dosiahnut' nemožno.

Tým sa dostávame k druhému problému s vágnostou. Principiálna „,nedourčenost“" jednotlivých pojmov je spôsobená viacerými okolnost’ami, z ktorých najzávažnejšou je problém kruhovosti definovania, respektíve otázky dostatočného precizovania pojmov inými pojmami. Z Quinových Dvoch dogiem empiricizmu (Quine 1951) vyplýva, že význam jednotlivých slov nie je daný bezprostredne nimi samými, ale skôr celou siet’ou významov ostatných slov, ktoré naň v systéme odkazujú. Takzvaná $Q$ paradigma bola predmetom pomerne jednoznačnej a úspešnej kritiky, pretože jedným z jej dôsledkov je nemožnost' prekladu. Pojmy sú však vždy definované v celom systéme - len tak sú usúvztažnené, čo umožňuje vysvetlit' preklad z jedného jazyka do druhého.

V prirodzenom jazyku nie sme spôsobilí presne definovat' významy všetkých jeho pojmov (respektíve žiadneho z nich s úplnou presnost'ou) a existujú významy, ktoré jednoducho nevyplývajú len z vnútorného deduktívneho aparátu daného jazyka. Istý stupeň neurčitosti je teda v jazyku celkom prirodzený, hoci (a na tom sa môžeme zhodnút') nemusí byt' niekedy žiaduci.

Timothy Williamson vo svojich prácach o vágnosti ukázal, že existencia vágnosti nie je nevyhnutne prekážkou pre logiku ani poznanie. To, že o hraniciach niektorých pojmov nemáme celkom určité poznatky, nám nebráni, aby sme robili pravdivé úsudky o objektoch, ktoré (zjavne) nie sú $F$, ani zjavne nie sú non $F$ (pozri napr. Williamson 2003, 709). Problémom sú hraničné prípady, teda také, o ktorých nevieme povedat', či sú $F$ alebo non $F$. Williamsovo vysvetlenie je aj tu prekvapivo zhovievavé.

${ }^{12}$ Neznamená to však, že každý presný text je nezrozumitel'ný, ani to, že zrozumitel'nost' možno dosiahnut' len za cenu nepresnosti.

${ }^{13}$ Miera presnosti je daná hornou hranicou vyjadrenou pomocou Planckovej konštanty. 
Nepochybuje, že aj v hraničných prípadoch tvoríme pravdivé alebo nepravdivé výroky o skutočnosti. Problémom je len to, že nevieme dostatočne presne, ktoré z nich sú pravdivé a ktoré nie. Ked’že veci poznáme vtedy a len vtedy, ak vieme, že vec sa má tak, ako ju opisujem, t’ažisko problému sa presúva z otázky pravdivosti na otázku istoty či zdôvodnenia. Williamson to však rieši bez potreby úplného zdôvodnenia toho, prečo viem, že viem. „Hoci pravdivost' $p$ je nevyhnutnou podmienkou toho, aby ktokol'vek mohol vediet', že $p$ nevyplýva z toho, že je súčast'ou nekruhovej nevyhnutnej a dostatočnej podmienky..." poznania (Démuth, Kutáš, Williamson 2014, 370). „Slovo ,vediet" sa učíme skôr tak, ako sa učíme slovo ,červený', t. j. pozorovaním príkladov jeho použitia, a nie tým, že nám niekto podá jeho analýzu“ (Démuth, Kutáš, Williamson 2014, 370). ${ }^{14}$ Naše výroky teda môžu byt' pravdivé, aj ked’ nedisponujeme úplným a nekruhovým dôkazom ich pravdivosti. Otázne pritom je, či v takomto prípade skutočne ide o poznanie $\mathrm{v}$ zmysle zdôvodneného pravdivého presvedčenia.

Niektorí autori sa preto nazdávajú, že ,vágnost’ je najlepším argumentom v prospech antirealizmu, a preto môže byt' prvým krokom s d'alekosiahlymi dôsledkami pre celý zvyšok jazyka“ [...] „Ak [však] vágnost' platí o čomkol’vek, tak platí aj o vágnosti“ (Démuth, Kutáš, Williamson 2014, 370). To znamená, že ani pojem vágnost' nie je celkom určitý. Kde sú hranice toho, čo už je dostatočne určité, a čo ešte nie? Kto ich určuje a ako?

\section{Kontextualizmus a sedimentácia hraníc významu}

V predchádzajúcich rokoch sa v slovenských a českých filozofických časopisoch diskutovalo o povahe skepticizmu a o podmienkach poznania. Jedným z klúčových momentov argumentácie Miloša Taligu bolo okrem iného presvedčenie, že poznanie sa nemôže opierat' o žiadne dostatočné alebo dobré dôvody (Taliga 2012, 2018). Taliga vo svojich štúdiách tvrdil, že naše poznanie nie je dostatočne zdôvodnitel'né, respektíve že jeho pravdivost' nemožno preukázat' ani dokázat'. Naopak, dokázat' a preukázat' možno len prípadnú nepravdivost' poznania. Problémom tohto postoja je, že ak viem, že niečo nie je pravda, tak musia existovat' dostatočné, alebo aspoň dobré dôvody pre takéto presvedčenie (že niečo nie je pravda), čo je v rozpore s pôvodnou tézou antijustifikacionalizmu. Taliga sa takémuto protirečeniu bráni tým, že žiadne dobré dôvody neexistujú, ${ }^{15}$ existujú len argumenty, ktorými dokazujeme (podl’a neho len preukazujeme) neplatnost' daných téz tým, že poukazujeme na ich dôsledky. Odhliadnuc od podrobností celej polemiky s Milošom Taligom a od toho, že podla viacerých autorov (Démuth 2012; Nuhlíček, Szapuová 2012; Gahér 2013; Démuth 2016) „,nerešpektuje bežnú jazykovú prax“ (Nuhlíček 2020, 338), je zrejmé, že v priebehu

\footnotetext{
${ }^{14}$ Porov. napr. Wittgenstein (2002).

15 Alebo ak aj existujú, sú nefunkčné (Taliga 2018, 439).
} 
zmysluplnej diskusie autora s iným autorom neraz dochádza k ozrejmovaniu významov pojmov, ktoré jednotliví diskutujúci vo „svojom“ jazyku používajú. Nie všetci totiž pod daným výrazom rozumieme celkom to isté, a to napriek tomu, že používame výrazy toho istého jazyka. Inak povedané, nezhodneme sa na denotáte použitých jazykových výrazov prirodzeného jazyka (,pravdivost““ či ,zrejmost”“ denotátu takéhoto výrazu potom závisí iba od jazykovej konvencie, teda od presvedčenia väčšiny o význame výrazu - čo však v konečnom dôsledku nemusí znamenat', že toto presvedčenie je správne, ale len to, že je väčšinové).

Williamson a iní zástancovia epistemicizmu zväčša veria, že významy slov sú pevne dané, respektíve že existuje pevná hranica pre to, kedy môžeme ten-ktorý termín aplikovat' a kedy už nie. Problémom vágnych pojmov podl'a nich je, že pri tomto druhu pojmov nie sme celkom dobre schopní určit', kedy máme a kedy už nemáme daný termín použit' na ich označovanie. To, o čo teda ide, je tvrdenie neznalosti sémantických hraníc vágnych pojmov a naša principiálna kognitívna neschopnost' tieto dané sémantické hranice rozoznávat'.

Za problematické považujeme práve presvedčenie o pevnosti a danosti významov, respektíve to, že existuje pevná a nemenná hranica, kedy možno daný termín aplikovat' a kedy už nie. Väčšina epistemológov predpokladá, že väčšinu významov slov si osvojujeme prevažne pasívne, učením sa jazyka (Sorensen 2018). Pripúštajú síce možnost' alternácie významu slov v čase, ale jazyk vnímajú viac-menej v statickej podobe. Významy pojmov sa však v čase neraz menia. ${ }^{16}$ Do jazyka sa dostávajú nové pojmy a významy, alebo tie už osvojené sa spresňujú a modifikujú - stačí si v televízii pozriet' film pre pamätníkov a pochopíme, že jazyk použitý v nich je z hl'adiska dnešného vnímania jazykovej konvencie skrátka archaický. Spravidla mu rozumieme (aj ked' pri nasledujúcej generácii to už nemusí platit'), ale vyžaduje si to istú dávku „,vcítenia“ do dobovej terminológie a spravidla i myslenia. Naopak, keby typický dobový divák prvorepublikovej kinematografie videl dnešný sci-fi film o Avengeroch, mal by problém pochopit' význam mnohých výrazov, použitých v odlišných jazykových, dobových či iných kontextoch - a niektorým slovám by podistým nerozumel vôbec, hoci pre nás sú samozrejmou súčast'ou tezauru slovnej zásoby. Navyše sa nevyhnutne nemusia menit' len jazykové výrazy, ale aj ich denotáty a významy. Presnejšie povedané, nemusí sa nutne menit' sám denotát výrazu, ale môže sa menit' jeho jazykový význam. Typický príklad takejto zmeny predstavuje výraz lod'. V tridsiatych rokoch dvadsiateho storočia by si pod ním užívatelia jazyka konzumenti zväčša predstavili niečo iné, ako divák súčasného sci-fi filmu. Obohacuje sa skupina objektov tvoriacich denotát výrazu jazyka, a tým sa posúva jeho význam. Pod výraz lod’ už subsumujeme viac

${ }^{16}$ O diachrónnej sedimentácii významov v jazyku pozri napr. Merleau-Ponty (1971). 
objektov reálneho sveta ako pred sto rokmi. Gramatické pravidlá pre užívanie jazykových výrazov, syntaktické a morfologické pravidlá ostávajú nezmenené, ale sémantika sa mení.

Jazyk tak možno pripodobnit' sémantickému a výrazovému pol'u, ktorého prvky sa neraz menia, preskupujú a významy jednotlivých pojmov emergujú z ich vzájomných vzt'ahov a v závislosti od obohacovania či používania jednotlivých prvkov jazyka kontextovo determinované sémantické obsahy (Zouhar 2011). Dôvody vágnosti pojmov teda nespočívajú len v epistemických príčinách a slabosti napríklad našich zmyslových orgánov (čo tvrdia epistemici), ale zároveň aj v nejasnosti významových hraníc niektorých pojmov ${ }^{17} \mathrm{v}$ sémantickom kontexte toho-ktorého užívatel'a daného jazyka. Zároveň platí, že prirodzený jazyk a jeho „oficiálna verzia“ nie sú dané zhora - apriórnym nariadením a kodifikáciou, ale skôr sú výsledkom pragmatickej lingvistickej teórie hier - rečových aktov a foriem dorozumievania - zohl'adňujúcim rôzne osobné, regionálne, profesijné, synchrónne a diachrónne podoby stretávania a približovania intencií a myslí prostredníctvom používania jazyka. ${ }^{18}$ Významy slov sú výsledkom - sedimentom spoločného i osobného ustal'ovania týchto vzt’ahov, ktorých absolútne presné hranice a polohy nemožno bezo zvyšku v žiadnej kodifikácii popísat'.

Niektorí filozofi používajú terminológiu, ktorej osvojenie si vyžaduje značnú námahu. Podaktorí používajú svoje pojmy programovo celkom odlišne ako iní, aby demonštrovali iné významy a chápanie ako ich predchodcovia. Iní zas preferujú významovú otvorenost' $\mathrm{v}$ záujme poetickosti ich jazyka či metaforickosti vyjadrovania, čím otvárajú nové pohl’ady na problémy a neraz tak ponúkajú nové riešenia (Nietzsche). Sú však aj takí, ktorých vágnost' tkvie v obyčajnej nepresnosti, nekonkrétnosti a nejasnosti myslenia. I tu je však pre upresňovanie pojmov a precizovanie nášho myslenia nezastupitel'ná úloha „toho druhého“, konzumenta.

\section{O možnej progresívnosti sémantickej vágnosti}

Mohlo by sa zdat', že ideálom dobrého vyjadrenia je minimalizovanie vágnosti a spresňovanie myslenia (spresňovaním vyjadrovania spresňujeme svoje myslenie). To je časovo, lexikálne aj energeticky často vel'mi náročné. ${ }^{19}$ Autori spomínaného článku tematizujúceho nepriamu úmernost' medzi presnost'ou a stručnost'ou výpovede

\footnotetext{
${ }^{17}$ Nejde tu teda o problém pragmatiky (používania) jazykových výrazov (či vieme alebo nevieme jednoznačne použit' jednotlivé termíny pre určité prípady) - čo by bolo možné stále chápat' ako istú verziu epistemicizmu - ale skôr o nejasnost' a neostrost' samotných pojmov - vágnost' ako problém sémantiky.

${ }_{18}$ Práve v tomto zmysle Peter Gärdenfors chápe jazyk ako priestor pre stretnutie dvoch myslí (Warglien, Gärdenfors 2013).

${ }^{19}$ Ako vyplýva z Blackmoreovej teórie memov (Blackmore 2000), zjednodušovanie (aj za cenu straty presnosti, detailnosti a ostrosti) je jednou z najpodstatnejších podmienok šíritel'nosti myšlienok a ich replikovatel'nosti v kultúrnom prostredí.
} 
sú si dobre vedomí, že existujú pojmy, ktoré „môžeme spresňovat', nahrádzat' presnejšími, ale dokonalú presnost' nedosiahneme. Ak je presnost' použitých pojmov v pragmatických situáciách dostatočná a sporné prípady sa nevyskytujú vôbec, alebo len vel'mi výnimočne, niet dôvodu nahrádzat' ich ostrejšími pojmami, respektíve menit' základné pojmy konceptuálnych sústav. Ak nerozhodnutých prípadov je nadkritické množstvo, pričom svojimi dôsledkami spôsobujú vážnejšie aplikačné problémy, tak je to podnet na redefinovanie pojmov, prípadne na zmenu celej konceptuálnej sústavy“ (Gahér et al 2020, 311). Vágnost' používaných pojmov však nemusí byt' v jazyku vždy na škodu. A to nielen preto, že určitá miera neurčitosti je jednoducho neodstránitel'ná a jej podkritické množstvo v jazyku spôsobuje pestrost' a nespôsobuje problémy. Naopak, neurčitost' (nie vágnost') môže slúžit' ako dejová zápletka či základ pre celé literárne štýly (dadaizmus), alebo ako prostý zdroj vtipu.

Často sa stáva, že najmä v nových situáciách nedisponujeme dostatočne jasnými konceptuálnymi schémami, ktoré by presne a jednoznačne opisovali naše intencie či daný stav. Ustálené jazykové formy nám jednoducho neponúkajú dostatočne výstižné výrazové prostriedky na opísanie niečoho nového. ${ }^{20}$ Ak dosiahneme spomínanú kritickú hranicu neurčitosti vyjadrenia z dôvodov nedostatočnej ponuky slovníka jazyka, sme nútení zavádzat' nové pojmy alebo redefinovat' celú používanú konceptuálnu sústavu. Určitá sémantická nejednoznačnost' a otvorenost' nám tak umožňujú upriamit' pozornost' na nové aspekty a významy, a to prostredníctvom slov, ktoré sa bežne používajú v inak ustálených významoch. Tak možno hovorit’ metaforicky nielen o prenášaní významu, ale rovnako tak aj o vytváraní celkom nových významov pôvodného výrazu. ${ }^{21}$ Príkladom takéhoto používania slov je Heideggerov jazyk. Jeho pojem Dasein znamená niečo celkom odlišné ako Hegelov pojem Dasein, a preto ho Heidegger v istom období písal odlišne ( $\mathrm{s}$, ,-y-“), aby poukázal na odlišnost' tohto pojmu od zaužívaného významu. Objasnenie toho, čo daný pojem u Heideggera znamená, bolo možné až použitím tohto pojmu v kontexte iných výrazov, ktorými ho objasňoval, respektíve ktoré naň odkazovali. Podobne tak nachádzame v dejinách vedy vel'mi

\footnotetext{
${ }^{20}$ Nejde o otázku používania - výberu konkrétnych jazykových výrazov, lež o ich absenciu alebo prílišnú neurčitost' existujúcich výrazov.

${ }^{21}$ Pre doplnenie je vhodné uviest', že miera vágnosti pojmu sa môže menit' u tých istých používatel’ov v závislosti od času (vo vývoji spojenia medzi výrazom a meniacimi sa významami počas určitého časového intervalu), ale aj individuálne - v závislosti od užívatel'ov v tom istom čase. Niektoré pojmy môžu mat' $v$ istom čase vágny význam, no ten sa postupne spresní (alebo naopak, ich význam sa ešte väčšmi rozostruje). Iné výrazy môžu mat' v istom časovom období vágny, alebo naopak dostatočne presný význam $\mathrm{M}_{1}$, no v inom čase nadobúdajú iný, neekvivalentný význam $\mathrm{M}_{2}$. A to ako pri používaní daných výrazov celou skupinou používatel'ov (sedimentovanie nových významov v jazyku), tak aj pri individuálnom použití toho istého výrazu jedným použivatel'om pre dva odlišné významy (v osobnom chápaní významov).
} 
častú stratégiu prenášania terminologického inventária jednej vedy do druhej (napríklad hydrauliky do freudovskej psychoanalýzy) a formovanie celkom nových myšlienok vd’aka istej sémantickej otvorenosti daných pojmov, ktoré prekračujú bežnú hranicu analógie. Keby boli dané pojmy chápané celkom presne a uzatvorene, takýto prenos by nebol celkom dobre možný, respektíve viedol by k nezmysluplným vyjadreniam.

Neuzavretá textúra pojmov ${ }^{22}$ (intenzionálna neurčitost') a revidovatel'nost' pravidiel však nielenže umožňuje vznik nových obsahov, ale aj ich obsahovú naplnenost' a primeranú flexibilnost' v čase. Príkladom takéhoto používania môžu byt' rôzne pojmy odborného (napríklad právneho), alebo aj prirodzeného jazyka. $\mathrm{V}$ iných prácach upozorňujeme na vel'mi pestrú paletu aplikácie poznatkov, z ktorých čast' rezonovala aj v tomto článku, na vel’mi pevné a schematizované pravidlá používania jazyka v normatívnych textoch (Števček 2018, 50 - 51). V tejto súvislosti tematizujeme pojem sémantiky normatívnej vágnosti ako péndant či podmnožinu vágnych pojmov prirodzeného jazyka (aj normatívny jazyk je súčast’ou prirodzeného jazyka).

Napríklad možno poukázat' na problematickost' na prvý pohl'ad nejasného rozsahu pojmu „dobré mravy“ $v$ právnej terminológii. Paradoxne práve táto neuzatvorenost' mu dáva trvácnost' a opodstatnenost' v (právnom) jazyku. Kým v minulom období daný pojem označoval isté formy konania, ktoré boli všeobecnou spoločenskou konvenciou vnímané ako morálne neprijatel'né, ${ }^{23}$ dnes rovnaké formy konania takto nehodnotíme. Zato pod daný pojem dnes zarad'ujeme iné formy konania, ktoré podeň v minulosti nemuseli patrit'. Rozsah tohto pojmu sa teda časom mení, hoci jeho obsah - mravná neprijatel'nost' - pretrváva viac-menej nezmenený. ${ }^{24}$ Podobne môžeme uvažovat' o viacerých pojmoch - napríklad starý mládenec (porovnaj aj Quine 1951 otázka veku, príslušnosti k pohlaviu, manželskému stavu, daňovej kategórie?). Práve neostrost' a všeobecnost' pojmu v niektorých prípadoch umožňujú „nat'ahovanie“ roz-

\footnotetext{
${ }^{22} \mathrm{Na}$ tomto mieste chceme pod'akovat' recenzentovi článku, ktorý nás upozornil na možné chápanie sémantickej otvorenosti pojmov, ktorá je podla viacerých autorov formulovatel'ná len na úrovni diachrónneho pohl'adu na jazyk, kým sémantickú vágnost' výrazov možno identifikovat' už (len) pri synchrónnom pohl'ade na jazyk. V predkladanej štúdii používame termín sémantickej neuzatvorenosti, resp. otvorenosti v súlade s prácou H. L. A. Harta (Hart 2010), ktorý otvorenost' pojmov chápe ako aktuálny (synchrónny) jav, hoci sme si vedomí i pôvodného významu Waismannovho pojmu otvorenej textúry (Porosität der Begriffe; Waismann 1945, 121) aj jeho kritík (napr. Gahér 2018; Bix 1991).

${ }^{23}$ Podl'a toho, či šlo o konanie v súlade s dobrými mravmi alebo nie.

${ }^{24}$ Sémantická vágnost' tohto pojmu netkvie len $\mathrm{v}$ tom, že v priebehu času sa spojenie medzi daným výrazom a rozsahom jeho uplatňovania zmenilo. Neurčitý je sám pojem, a to ako v nejakom pôvodnom čase $t_{1}$, tak v nasledujúcom čase $t_{2}$. Dôvod neurčitosti pojmu pritom nie je v tom, na čo má byt' aplikovaný a na čo už nie, ale priamo v jeho definovaní: „Dobrými mravmi sú pravidlá správania sa, ktoré sú $v$ prevažnej miere $\mathrm{v}$ spoločnosti uznávané a tvoria základ fundamentálneho hodnotového poriadku” (Uznesenie Ústavného súdu SR z 24. 2. 2011, č. k. IV. ÚS 55/2011-19).
} 
sahu pojmov a ich aplikovanie aj v ustavične sa meniacom prostredí. Napríklad všeobecný pojem dom sa s meniacim prostredím začal aplikovat' aj na výrazy byt či hotel, aby sa dospelo opät' $k$ zovšeobecneniu pod pojem obydlie. Podkritická vágnost' je tak predpokladom pružnosti významov, a tým istej stability aplikácie slovných spojení. Osobitne dobre to platí pre etiku a právo, ktoré vždy reagujú aj na nové formy správania. Prijatie nejakej normy totiž môže aj pod tlakom nových poznatkov viest' k novým, na pôvodnú normu reagujúcim formám konania, a preto bude $\mathrm{v}$ relatívne krátkom čase potrebné danú etickú či právnu normu spresnit', doplnit' - najskôr interpretáciou ako kognitívnym postupom, ktorým subsumujeme pod pôvodný výraz nový denotát, a tým posunieme jeho význam -, a v krajnom prípade (najmä pri prekročení onej kritickej hranice vágnosti) i novelizovat'. ${ }^{25}$ Preto nemá celkom zmysel pokúšat' sa mnohé etické či právne pojmy presne definovat' prostredníctvom ich taxonomického vymenúvania, ale skôr zahrnút' ich pod všeobecnejší pojem, ktorý vymedzuje hlavnú intenciu zákonodarcu (samozrejme, to už ipso facto nie je otázka vágnosti). Tak nebude dochádzat' $\mathrm{k}$ tomu, že mravné a právne normy sa budú ustavične rozrastat', ani sa sústavne menit' či spresňovat', ale skôr získajú trvácnost' (sémantickú, a tým i právnu istotu), čo prinesie aj ich presnejšie aplikovanie pri bežnom užívaní jazyka.

\section{Záver}

Možno namietat', že prílišná nejasnost' pojmov znemožňuje porozumenie a primárnou funkciou jazyka má byt' práve komunikovat' obsahy tak, aby boli jasne zrozumitel'né. $\mathrm{Z}$ toho vyplýva, že vágnost' pojmov by mala byt' $v$ jazyku akosi ,programovo“ obmedzovaná.

Uvedená úvaha nie je obhajobou vágnosti v tom zmysle, že by sme sa o ňu mali pokúšat'. A nie je ani obhajobou tézy, že vágnost' je ontologickou povahou sveta či javov v ňom. Práve naopak - ontologickú vágnost' odmietame. Svet je taký, aký je, a nejasné môže byt' len naše poznanie o ňom, prípadne jazykové formulácie, ktorými ho opisujeme. V súlade s epistemicizmom sme sa však pokúsili ukázat', že ani pri najlepšej vôli nemožno spoznat' svet vo všetkých jeho detailoch, ktoré by boli nezávislé od našich sémantických východísk; že naše výpovede o svete často nie sú, a ani nemôžu byt' celkom jasne a úplne definované. Zároveň sme sa pokúsili ukázat', že istá miera vágnosti je v jazyku principiálne neodstránitel'ná, ale i to, že vágnost' ako taká ešte nie je prekážkou pre možné poznanie a porozumenie. Naopak, primeraná miera sémantickej neuzatvorenosti či otvorenosti umožňuje jedincom vôbec komunikovat', teda $\mathrm{v}$ priestore logickej sémantiky verbalizovat' dve rozdielne sémantické sústavy v oblasti jazykovej pragmatiky a psychologizmu komunikácie možno hovorit' o tom,

\footnotetext{
${ }^{25}$ Osobitne to platí napríklad pre oblast' finančníctva, daní a hospodárstva.
} 
že subjektívnou skúsenost’ou nadobudnuté významy slov (to, ako slovám subjektívne rozumieme) možno obohacovat' o nové dimenzie a aspekty, a tým približovat' svoj sémantický priestor k sémantickému priestoru niekoho iného. Úplné splynutie dvoch sémantických priestorov nie je asi celkom možné, ale nie je ani potrebné. Ak narazíme na privel'kú mieru nejasnosti, nejednoznačnosti či odlišností, tá sa dá v prípade záujmu postupne eliminovat', a to dodatočným explicitným spresňovaním alebo dedukciou (vyjavovaním) pôvodného zámeru z kontextu, v akom sa pojmy používajú. Zároveň umožňuje akcentovat' všeobecnost' a intenzionálnu nemennost' v protiklade $\mathrm{k}$ extenzionálnej premenlivosti. Zdokonal'ovat' presnost' a jasnost' možno totiž (takmer) donekonečna.

\section{Literatúra}

BIX, B. (1991): H. L. A. Hart and the "open texture" of language. Law Philosophy, (10), 51 - 72. DOI: https://doi.org/10.1007/BF00144295

BLACKMOREOVÁ, S. (2000): Teorie memů. Praha: Portál.

BOBZIEN, S. (2020): Vagueness and Indeterminacy. [online]. Dostupné na: https://philpapers.org/ browse/vagueness-and-indeterminacy (Navštívené: 3. 3. 2021).

DÉMUTH, A. (2012): Môže skeptik skutočne pochybovat' o všetkom? (Odpoved' M. Taligovi). Filozofia, 67 (2), 141 - 146.

DÉMUTH, A. (2016): Skepticizmus - rôzne podoby, rôzne problémy. Filosofický časopis, 64 (5), $705-723$.

DÉMUTH, A., KUTÁŠ, M., WILLIAMSON, T. (2014): Filozofia filozofie. Filozofia, 69 (4), 366 - 373.

DVOŘÁK, P. (2019): Je vágnost' sémantický či ontický fenomén? Filosofický časopis, 67 (4), 485 - 502.

EVANS, G. (1978): Can There Be Vague Objects? Analysis, 38 (4), 208. DOI: https://doi.org/ 10.1093/analys/38.4.208

GAHÉR, F. (2013): Je zdôvodňovanie naozaj zbytočné? Filozofia, 68 (2), 132 -138.

GAHÉR, F. (2018): Otvorená textúra - pôvodný zmysel a kritika. Filozofia, 73 (8), 620 - 635.

GAHÉR, F., MRVA, M., ŠTEVČEK, M., TURČAN, M. (2020): Otvorená textúra pojmov a pravidiel - voda na mlyn pre subjektivizmus v aplikovanej sémantike? Filozofia, 75 (4), 309 - 323. DOI: https://doi.org/10.31577/filozofia.2020.75.4.4

GÄRDENFORS, P., DÉMUTH, A. (2013): Geometrizovanie významu. Rozhovor s Petrom Gärdenforsom. Filozofia, 68 (7), $621-624$.

HART, H. L. A. (2010): Pojem práva. Český Těšín: Prostor.

HEISENBERG, W. (1927): Über den anschaulichen Inhalt der quantentheoretischen Kinematik und Mechanik, Zeitschrift für Physik, 43 (3 - 4), 172 - 198.

HOLLÄNDER, P. (1995): Paradox právneho jazyka. Kultúra slova. Vedecko-popularizačný časopis pre jazykovú kultúru a terminológiu, 6, 328 - 331. Martin: Vydavatel'stvo Matice slovenskej. [online]. Dostupné na: www.juls.savba.sk/ediela/ks/1995/6/ks1995-6.html (Navštívené: 1. 2. 2021).

HYDE, D., RAFFMAN, D., (2018): "Sorites Paradox". In: Zalta, E. N. (ed.): The Stanford Encyclopedia of Philosophy (Summer 2018 Edition). Dostupné na: https://plato.stanford.edu/ archives/sum2018/entries/sorites-paradox/ (Navštívené: 1. 2. 2021).

MERLEAU-PONTY, M. (1971): O fenomenologii řeči. In: Oko a duch a jiné eseje. Praha: Obelisk, $95-107$.

NUHLÍČEK, M. (2020): Taliga Miloš: Kritický racionalizmus a metóda falzifikácie. Filozofia, 75 (4), 334 - 338. DOI: https://doi.org/10.31577/filozofia.2020.75.4.7 
NUHLÍČEK, M., SZAPUOVÁ, M. (2012): Poznámky ku skepticizmu alebo čo spochybňuje, a čo nespochybňuje skeptik. Filozofia, 67 (2), 147 - 159.

PEREGRIN, J. (2004): Logika a logiky. Praha: Academia.

QUINE, W. V. O. (1951): Two Dogmas of Empiricism. The Philosophical Review, 60 (1), 20 - 43.

SORENSEN, R. (2018): "Vagueness". In: Zalta, E. N. (ed.): The Stanford Encyclopedia of Philosophy (Summer 2018 Edition), Dostupné na: https://plato.stanford.edu/archives/sum2018/entries/ vagueness/ (Navštívené: 1. 2. 2021).

ŠTEVČEK, M. (2018): Sémantika vágnych pojmov. Bakalárska práca. Trnava: Filozofická fakulta Trnavskej univerzity v Trnave.

TALIGA, M. (2018): Kritický racionalizmus a skepticizmus. Filosofický casopis, 66 (3), 433 - 441.

TALIGA, M. (2012): Na čo sú dobré argumenty? (Odpoved’ A. Démuthovi, M. Nuhlíčkovi a M. Szapuovej). Filozofia, 67 (5), $423-424$.

UZNESENIE ÚSTAVNÉHO SÚDU SR z 24. 2. 2011, č. k. IV. ÚS 55/2011-19.

VECSEY, Z. (2012): On the epistemic status of borderline cases. Principia, 16 (1), 179 - 184.

WAISMANN, F. (1945): Verifiability. Proceedings of the Aristotelian Society. Supplementary Volume XIX, 120 - 150. Dostupné na: http://users.umiacs.umd.edu/ horty/courses/readings/ waismann-verifiability.pdf (Navštívené: 1 . 2. 2021).

WARGLIEN, M., GÄRDENFORS, P. (2013): Semantics, conceptual spaces and the meeting of minds. Synthese, 190 (12), 1 - 29.

WILLIAMSON, T. (1994): Vagueness. London: Routledge.

WILLIAMSON, T. (2013): Vagueness in Reality. In Loux, M. - Zimmerman, D. (eds.): The Oxford Handbook of Metaphysics. Oxford: Oxford University Press, 690 - 715.

WITTGENSTEIN, L. (2002): Modrá a Hnedá kniha. Bratislava: Kalligram.

ZOUHAR, M. (2011): Význam v kontexte. Bratislava: Aleph, edícia Noema.

Táto práca bola podporená Agentúrou na podporu výskumu a vývoja na základe Zmluvy č. APVV18-0199.

Andrej Démuth

Právnická fakulta

Univerzita Komenského v Bratislave

Šafárikovo námestie 6

81000 Bratislava

Slovenská republika

e-mail: andrej.demuth@uniba.sk

ORCID ID: https://orcid.org/0000-0003-3133-2908
Marek Števček

Právnická fakulta

Univerzita Komenského v Bratislave

Šafárikovo námestie 6

81000 Bratislava

Slovenská republika

e-mail: marek.stevcek@uniba.sk

ORCID ID: https://orcid.org/0000-0002-8154-2375 